\title{
Meanings of Methodological Individualism
}

\author{
Geoffrey M. Hodgson
}

Published in the Journal of Economic Methodology, 14(2), June, pp. 211-26.

KEY WORDS:

methodological individualism, social relations, social structures, Joseph Schumpeter

JEL classification, B20, B40, B41

\begin{abstract}
Advocacy of 'methodological individualism' is a widespread, especially among economists. However, the term is rarely defined with adequate precision and some crucial ambiguities are explored in this article. Among these is the commonplace ambivalence over whether explanations should be in terms of individuals alone, or in terms of individuals plus relations between them. It is shown that a great deal hinges on this subtle and often overlooked distinction in explanantia. In particular, explanations in terms of individuals alone have never, as yet, been achieved. Furthermore, the more feasible version of explanations in terms of individuals plus relations between them amount to the introduction of social structure alongside individuals in the explanantia. Serious questions remain whether this version warrants the one-sided emphasis on individuals in the term 'methodological individualism'.
\end{abstract}

\section{Introduction}

As in most sciences, the majority of economists do their work with little explicit reflection on the philosophical assumptions that underlie their research. ${ }^{1}$ But insofar as economists make their philosophical assumptions explicit, claims to adhere to 'methodological individualism' are uppermost.

Although there are different meanings of the term, they generally insist on the importance of individuals and their purposeful behaviour. This emphasis on the individual in the analysis of socio-economic phenomena becomes prominent with the Enlightenment, and is it found in the works of numerous authors, including John Locke and Jeremy Bentham (Udéhn, 2001). Accordingly, some key ideas behind the term have a much longer history than the term itself.

\footnotetext{
1 The author warmly thanks Bruce Caldwell, John Davis, Alex Field, Ernesto Screpanti, Lars Udéhn, Viktor Vanberg and two anonymous referees for very helpful comments on earlier versions of this paper.
} 
The term 'methodological individualism' was not invented by a philosopher but by a leading economist. A chapter of a book in German published by Joseph Schumpeter (1908) is entitled 'Der methodologische Individualismus'. Schumpeter (1909) distilled some of the ideas in his 1908 text into an article published in the Quarterly Journal of Economics. It is here that the term 'methodological individualism' first appears in an academic work in English. $^{2}$

The term itself does not re-emerge in a large database of leading academic journals until the 1930s and, where it received only a brief mention by John Hicks (1934) and Fritz Machlup 1937). ${ }^{3}$ In the 1940s, Austrian School economists such as Friedrich Hayek (1942) and Ludwig von Mises (1949) linked the phrase to their own methodological position. Perhaps influenced by his friendship with Hayek, Karl Popper (1945a) mentioned the term briefly in an article in Economica. ${ }^{4}$ Popper (1945b) developed his interpretation of the concept and brought it to the attention of philosophers.

Ironically (although no causal connection is suggested) after Schumpeter's death in 1950 the term began to be used more frequently. Popper's student John W. N. Watkins (1952a, 1952b) advocated a version of the doctrine and stimulated a protracted controversy in the philosophical literature. ${ }^{5}$ In the 1960 s the phrase made its first appearance in a leading sociological journal (Dore, 1961). Accordingly, through the Austrian trinity of Schumpeter, Hayek and von Mises, the term 'methodological individualism' was exported from economics into other disciplines.

However, overviews of the history and controversies surrounding the term establish that it has no single accepted meaning (Lukes, 1969; O’Neill, 1973; Udéhn, 2001, 2002). Despite its frequent appearance, there is no consensus on its sense and usage. Hence there is no warrant for the incantation of its two words without reference to an adequate definition.

A purpose of this article is to explore some crucial ambiguities in the use of the term and then to focus in its most prominent and plausible range of meanings. Some critical observations are offered. Sections 2-4 explore some major ambiguities in the use of the term. The ambiguity discussed in section 4 is the most pertinent for the discussion here and elsewhere. Section 5 proposes the 'folk theorem' that in practice explanations of social phenomena are never in terms of individuals alone. Section 6 refocuses on the crucial ambivalence in the use of the term exposed in section 4. It shows that the two possible interpretations of the idea that social phenomena must be explained in terms of individuals

\footnotetext{
2 Schumpeter's teacher, Max Weber (1968) promoted a position that has since been described as methodological individualism in the first chapter of his Economy and Society, published after his death in 1920.
}

\footnotetext{
3 The reference here is to the JSTOR database, which covers economics and other social sciences and includes leading journals in economics. JSTOR user services and information on the journals contained can be contacted via jstorinfo@umich.edu or jstor@mimas.ac.uk.

${ }^{4}$ Popper’s Economica essays on 'historicism’ were eventually worked up into a book (Popper, 1960).

5 Another student of Popper, Joseph Agassi (1960, 1975), also made noted contributions to the debate. He invented and advocated the term 'institutional individualism' as a replacement, in recognition that institutional structures exist and affect individual choices, while only individuals have aims and responsibilities. But many proponents of ‘methodological individualism' take a similar view.
} 
either violate the folk theorem or do not warrant the label of methodological individualism. Section 7 concludes the essay.

\section{Ambiguity (A) - Universal Methodological Imperative or (Sub)Disciplinary Demarcation Device?}

Schumpeter gave the term a meaning that is less prominent today. For Schumpeter (1908, p. 91) methodological individualism 'just means that one starts from the individual in order to describe certain economic relationships.' He was emphatic that this statement of methodological conduct implies no political position; methodological and political individualism are logically separate and propositionally distinct. Subsequent authors have repeated this point, but in some accounts these analytical and normative issues have been confused. 6

Importantly, for Schumpeter, methodological individualism was no universal injunction or methodological principle from which we depart at our peril. Instead for him it was an attempt to demarcate the 'pure theory' of economics from other approaches and methods of scientific inquiry. For 'pure theory', according to Schumpeter (1909, p. 216), 'it is irrelevant why people demand certain goods: the only important point is that all things are demanded, produced, and paid for because individuals want them.' He fully admitted that individual preferences could be malleable, but investigations into the causes of those preference changes were outside the scope of 'pure theory'. Hence an explanatory 'division of labor' existed between the 'pure theory' of economics, and other scientific approaches (Schumpeter, 1954, p. 889).

For Schumpeter, this proposal for a 'division of labor' was a means of reconciling the two sides in the ongoing Methodenstreit. One side was seen as concerned with 'pure theory' and the other addressed broader issues, including the explanation of individual tastes. As Schumpeter (1908, pp. 6-7) wrote: 'both sides are mostly right ... their sole difference lies in their interests in different problems.' Hence Schumpeter upheld methodological individualism as neither a universal principle of social scientific research nor an obligatory rule for all social scientists.

Importantly, Schumpeter (1954, p. 888) coined the different term 'sociological individualism' to describe the doctrine that

the self-governing individual constitutes the ultimate unit of the social sciences; and that all social phenomena resolve themselves into decisions and actions of individuals that need not or cannot be further analysed in terms of superindividual factors.

This 'sociological individualism' is close to what many people today describe as 'methodological individualism'. However, Schumpeter (pp. 888-9) immediately rejected this doctrine as unviable as a complete explanation: 'This view is, of course, untenable so far as it implies a theory of the social process.' Unfortunately he did not expand further on this point, other than contrasting 'sociological individualism' with 'methodological individualism'. The wording and context suggests that Schumpeter meant that 'sociological individualism' was

\footnotetext{
6 This applies to both critics and exponents. Hayek (1948) used the looser term 'individualism' to refer to both political and methodological doctrines. By the individual, advocates of methodological individualism refer to a singular human being. I follow the same usage of the term here, and I do not attempt to explore further its meaning.
} 
limited because it failed to explain the 'decisions and actions of individuals' themselves. Given this criticism by Schumpeter, and the fact that his definition of 'sociological individualism' is close to what many people mean by 'methodological individualism', it is clear that he should not be associated with many prominent versions of 'methodological individualism' that are promoted today.

Schumpeter regarded 'methodological individualism' as a limited analytical option, characteristic of 'pure economics'. By contrast, since his death, most advocates and opponents of 'methodological individualism' have treated it as a purportedly universal principle for use in the social sciences. The subsequent consideration of the different meanings of methodological individualism is confined to the period after the Second World War, when its use became prominent.

\section{Ambiguity (B) - Is it about Social Ontology or Social Explanation?}

Statements about what exists, or the nature of reality, are very different in character from statements concerning how one should explain phenomena. The first kind of statement is ontological, the latter is methodological. Two different and compatible explanations might be about the same thing, showing that (methodological) explanations are different from the (ontological) entities addressed. However, several authors confuse ontological with methodological individualism. ${ }^{7}$

For example, in a section in his book Human Action entitled 'the principle of methodological individualism' von Mises (1949, pp. 41-3) provides no clear definition of the term and includes statements such as: 'The hangman, not the state, executes a criminal. ... For a social collective has no existence and reality outside of the individual members' actions. The life of a collective is lived in the actions of individuals constituting its body. ... There is no substratum of society other than the actions of individuals.' All of these quoted statements are ontological rather than methodological in character.

The philosopher Watkins (1957, pp. 105-6) conflates both ontological and methodological individualism in a single passage. He upholds that 'the principle of methodological individualism' means that 'the ultimate constituents of the world are individual people who act more or less appropriately in the light of their dispositions and understanding of their situation. ... we shall not have arrived at rock-bottom explanations of such large-scale [social] phenomena until we have deduced an account of them from statements about the dispositions, beliefs, resources and inter-relations of individuals.' Statements concerning 'the ultimate constituents of the world' are ontological in character. Watkins then moves on to make a methodological statement, concerning 'rock-bottom explanations'.

This frequent conflation by enthusiasts of 'methodological individualism' may indicate an allegiance to ontological individualism as well. However, in ontological mode, a further crucial ambiguity arises. For reasons that will become clearer below, it is crucial whether it is claimed that the social world simply consists or individuals, or of individuals and interactive

\footnotetext{
7 Note that, as ontological presuppositions do not require any claims concerning explanation. Obversely, methodological individualism by many accounts does not necessitate ontological individualism, because many methodological individualists accept that the social world does not only consist of individuals, but also of interactive relations between them, and that social entities such as institutions exist.
} 
relations between them. The social world, by virtue of the fact that it is social, must involve such interactive relations. ${ }^{8}$

This point is clarified in modern accounts of social ontology (Bunge, 2000; Weissman, 2000). Hayek (1967, pp. 70-1), who is often (but questionably) described as an advocate of methodological individualism, makes a similar point:

The overall order of actions in a group is in two respects more than the totality of regularities observable in the actions of the individuals and cannot be wholly reduced to them. It is so not only in the trivial sense in which the whole is more than the mere sum of its parts but presupposes also that these elements are related to each other in a particular manner. It is more also because the existence of those relations which are essential for the existence of the whole cannot be accounted for wholly by the interaction of the parts but only by their interaction with an outside world both of the individual parts and the whole.

Following Hayek, society consists not merely of individuals, but also of interactions between individuals, plus interactions between individuals and other aspects of their environment including, presumably, both the natural world and other socio-economic systems. ${ }^{9}$

The brief discussion of social ontology in this subsection has not only emphasised the difference between ontological and methodological individualism, but also identified an additional ambiguity that becomes crucial at the methodological level. As shown below, some versions of methodological individualism require that social phenomena be fully explained in terms of individuals alone, while other versions require that they be explained in terms of individuals plus other critical factors, including interactions between individuals. A great deal hinges on this brief but enormously significant distinction.

\section{Ambiguity (C) - Does it Mean Explanation in Terms of Individuals, or Individuals Alone?}

Consider the following selected attempts to define methodological individualism: For Popper (1945b, vol. 2, p. 87), “"methodological individualism” ... rightly insists that the "behaviour” and the "actions" of collectives, such as states or social groups, must be reduced to the behaviour and to the actions of human individuals.' This use of the term 'reduced' here suggests that explanations should consist exclusively of statements about individuals.

However, Popper (1945b, vol. 2, p. 91) goes on to modify this significantly, by seeing methodological individualism more fully as 'the important doctrine that all social phenomena, and especially the functioning of all social institutions, should always be understood as resulting from the decisions, actions, attitudes, etc., of human individuals, and that we should never be satisfied by an explanation in terms of so-called "collectives" (states, nations, races,

\footnotetext{
8 The term 'social' here is used in a broad sense, to encompass phenomena that are examined in economics, as well as other social sciences. In the social context all reltions between individuals are causal and interactive, at least in the sense that in maintaining these relations with others, individuals are affected by their (partial) awareness of them and different actions may be enabled. Accordingly the term 'interactive relations' in the social context can be replaced by just 'relations'.

${ }^{9}$ Udéhn (2001), Caldwell (2004) and Zwirn (forthcoming) argue that Hayek - at least in his mature works implicitly abandoned dominant contemporary interpretations of methodological individualism.
} 
etc.).' This omits the requirement of complete explanatory reduction to individuals, and does not imply that explanations should be in terms of individuals alone. Instead, he claims that explanations (exclusively or otherwise) in terms of collectives are unsatisfactory.

As quote above, the definition of methodological individualism by Watkins (1957, p. 106) is broad in that does not reduce explanations of social phenomena to individuals alone, but also includes 'resources and inter-relations of individuals'. The latter term admits a huge class of phenomena, including social relations.

For Ludwig Lachmann (1969, p. 94) methodological individualism means 'that we shall not be satisfied with any type of explanation of social phenomena which does not lead us ultimately to a human plan.' But very few social scientists would deny the role of individual intentions in the explanation of social phenomena. Again, this definition of methodological individualism is so broad that it would be difficult to find a social scientist who disagrees.

Jon Elster (1982, p. 453) defines methodological individualism as 'the doctrine that all social phenomena (their structure and their change) are in principle explicable only in terms of individuals - their properties, goals, and beliefs.' Being less banal, this definition also is insufficiently precise, as it fails to clarify whether interactions between individuals or social relations are 'properties ... of individuals' or not. If neither individual interactions nor social relations are 'properties of individuals', then this narrower and more meaningful notion of methodological individualism points to explanations in terms of individuals alone. But it is not clear whether Elster means this or not.

Similar ambiguities are present in methodological statements by prominent mainstream economists. Frank Hahn (1984, p. 1) writes: 'I am a reductionist in that I attempt to locate explanations in the actions of individual agents.' Again this highlights the importance of individuals in the account, but fails to make it clear whether anything additional to individuals is permissible in the explanation.

By contrast, Geoffrey Brennan and Gordon Tullock (1982, p. 225) advocate a methodological individualism in which 'the ultimate unit of analysis is always the individual; more aggregative analysis must be regarded as only provisionally legitimate.' This contrasts with several other definitions, by being much more narrow in terms of its explanantia. ${ }^{10} \mathrm{It}$ seems to uphold the ultimate aim of explanation in terms of individuals alone.

It is shown below that a great deal hinges on this issue: does methodological individualism simply point to the importance of individuals in explanations of social phenomena, or does it insist that explanations should be reduced to individuals alone? Clearly, there is no consensus among advocates of methodological individualism on this crucial point concerning the explanantia. As Udéhn (2002, p. 498) puts it: 'The doctrine of methodological individualism, then, ranges from versions requiring that social phenomena be fully explained in terms of individuals, to versions requiring only that they be partly explained in terms of individuals.' 11

\section{A Folk Theorem Concerning Explanations of Social Phenomena}

10 An explanans (plural, explanantia) is an element that purportedly helps to explain something else, the explanandum (plural, explananda). Apologies to those who already know their Latin.

11 See also Kincaid (1997) for a further dissection of this and further ambiguities. 
The key proposition to be discussed in this section is that all satisfactory and successful explanations of social phenomena (including in economics) involve interactive relations between individuals. In other words, when explanations are reduced to individuals, interactive relations between individuals are also always involved. Because no formal proof will be offered of this proposition it will be referred to as a 'folk theorem'. Nevertheless, there are strong arguments in its favour.

By assumption, this folk theorem is confined to social situations. These by definition involve two or more individuals. Some economists have been enamoured by the example of Robinson Crusoe (before the arrival of Friday) allocating his scarce resources between competing ends, but the social characteristics of such a situation are limited. We are concerned with social phenomena, which necessarily involve more than one individual.

In the social sciences, are there any successful explanations of social phenomena in terms of individuals alone? Udéhn (2001) claims that social contract theory and general equilibrium theory are examples of explanations that involve individuals alone, without social relations or institutions. However, Kenneth Arrow (1994) denies this, by pointing out that price mechanisms involve social interactions and structures, and social phenomena that cannot be reduced entirely to individuals alone. Arrow (1994, pp. 4-5) remarked 'economic theories require social elements as well even under the strictest acceptance of standard economic assumptions ... individual behavior is always mediated by social relations. These are as much part of the description of reality as in individual behavior.'

Arrow is surely right on this point. All versions of social contract theory and general equilibrium theory involve individuals communicating with others or, at least, adopting tacit presumptions of the intentions and stances of others. All such interactions presume rules of interaction or interpretation. Trading in models of market interaction presumes some form of communication over prices or quantities. Communication involves some form of language, and languages by their nature are systems of rules. Furthermore, exchange involves the transfer of property rights, with rules established through prior social interactions. Similarly, all contracts rely on social structures of enforcement. Hence social contract theory and general equilibrium theory both presume structured relations between individuals, rather than individuals in isolation. They also presume relations between individuals and social institutions. For example, property rights require some system of enforcement. These things may not be stated explicitly in the models, but they are presupposed.

Individual choice requires a conceptual framework to make sense of the world. The reception of information by an individual requires a paradigm or cognitive frame to process and make sense of that information. The acquisition of this cognitive apparatus involves processes of socialization and education, involving extensive interaction with others (Douglas, 1986; Hodgson, 1988; Bogdan, 2000). The means of our understanding of the world are necessarily acquired through social relationships and interactions. Cognition is a social as well as an individual process. Individual choice is impossible without these institutions and interactions.

Alexander Field $(1979,1981,1984)$ has shown that key attempts by economists to explain the origin of social institutions presume individuals acting in a particular context, with rules of behaviour governing their interaction. In the presumed 'state of nature' from which institutions are seen to have emerged, a number of weighty rules, structures and cultural and social norms have already been (implicitly or explicitly) assumed. Accordingly, with explanations of the origin of institutions through game theory, Field pointed out that several constraints norms and rules must inevitably be presumed at the start. There can be no games 
without constraints or rules, and thus game theory can never explain the elemental constraints or rules themselves. Even in a sequence of repeated games, or of games about other (nested) games, at least one game or meta-game, with a structure and payoffs, must be assumed at the outset.

Similarly, social theorist Kyriakos Kontopoulos (1993, p. 79) noted that 'a methodological individualist strategy necessarily incorporates references to social relations'. As these critics have showed, claimed methodological individualists never start from individuals alone. For example, Steven Lukes (1973, pp. 121-2) shows that in the claimed 'methodological individualism' of Karl Popper 'the social phenomena have not really been eliminated; they have been swept under the carpet'. To get anywhere, we always have to assume relations between individuals, as well as individuals themselves. The works of methodological individualists themselves underline this point, and no counter-example is evident.

The proposition that explanations cannot be reduced to individuals alone has now taken hold in the new institutional economics. Jack Knight (1992) criticizes the preceding literature for neglecting the importance of distributional and power considerations in the emergence and development of institutions. Masahito Aoki (2001) argues that always and unavoidably, analysis must start from individuals plus some institutions, however primitive. He not only took individuals as given, but also assumed a historically bestowed set of institutions. With these materials, he explored the evolution of further institutions. With these studies, the goal of narrow methodological individualism is abandoned.

The narrow methodological individualist has a problem of infinite regress: attempts to explain each emergent layer of institutions always rely on previous institutions and rules. If institutional influences on individuals are admitted, then these too are worthy of explanation. In turn, the explanation of those may be partly in terms of other purposeful individuals. But where should the analysis stop? The purposes of an individual could be partly explained by relevant institutions, culture and so on. These, in their turn, would be partly explained in terms of other individuals. But these individual purposes and actions could then be partly explained by cultural and institutional factors, and so on, indefinitely. As long as we are addressing social phenomena, we never reach an end point where there are isolated individuals, and nothing more. We are involved in an apparently infinite regress, similar to the puzzle 'which came first, the chicken or the egg?' In this infinite regress, neither individual nor institutional factors have legitimate explanatory primacy (Nozick, 1977; Hodgson, 1988).

This problem has a parallel in biology: it is like to trying to talk about the effects of genes without environments, and commonly recognized to be a dead end. Social scientists should likewise acknowledge that consideration of individuals without an institutional context is also a non-starter.

All theories must first build from elements which are taken as given. However, the particular problems identified here undermine any claim that the explanation of the emergence of institutions can start from some kind of institution-free ensemble of (rational) individuals in which there is supposedly no rule or institution to be explained. Consequently, the project to explain the emergence of institutions on the basis of given individuals runs into difficulties, particularly with regard to the conceptualization of the initial state of nature from which institutions are supposed to emerge. 
A powerful body of evidence and argument supports the folk theorem. One counterexample would be sufficient to undermine it. None has yet emerged. ${ }^{12}$

\section{The Crucial Ambivalence}

As emphasised above, much of the confusion in the debate over methodological individualism stems from whether methodological individualism means one or other of the following:

(a) social phenomena should be explained entirely in terms of individuals alone; or

(b) social phenomena should be explained in terms of individuals plus relations between individuals.

The first of these versions (a) has never been achieved in practice, for reasons given above. It has been also shown above that many advocates of methodological individualism fail to specify this doctrine clearly in such narrow terms. It is just as well, as version (a) is unattainable in practice.

By contrast, the problem with the second version (b) is that not that it is wrong but the term 'methodological individualism' is unwarranted. The critique here is brief but no less devastating. In modern social theory, structures are typically defined as sets of interactive relations between individuals.

These interactive relations may include social positions filled by individuals (such as prime minister, production manager, or sales representative). A social position is a specified social relationship with other individuals or social positions, which might in principle be occupied by alternative individuals. When an individual occupies a social position, he or she brings not only his or her own qualities or powers, but acquires additional qualities or powers associated with that position, by virtue of relations with others.

By definition, institutions may be treated as a special case of social structure, involving systems of widely observed rules (Hodgson, 2006). The existence of a social position implies the existence of an institution with rules associated with that position.

The philosophical literature on emergent properties establishes that novel properties may emerge when entities interact, properties that are not possessed by the entities taken in isolation. Hence water has properties that are not possessed by hydrogen and oxygen. Hence the admission of 'interactive relations between individuals' in the definition of methodological individualism opens the door to properties that are emergent, and not the properties of individuals, taken severally.

Crucially, if social structures are equivalent to relations between individuals, then (b) is equivalent to:

$(b+)$ social phenomena should be explained in terms of individuals and social structures.

The problem then becomes one more of labels than of content. Although (b) and (b+) are both acceptable statements, there is no good reason why they should be described as

\footnotetext{
12 In apparently conciliatory statements, Sober (1981) and Kincaid (1997) argue that the validity or invalidity of methodological individualism is ultimately an empirical issue. If that is the case, then the evidence is against the narrow version. No significant explanation of social phenomena in terms of individuals alone has yet been advanced. In practice there is always a social and relational residual that is not reduced entirely to individual terms.
} 
methodological individualism. It would be equally legitimate to describe them as 'methodological structuralism' or 'methodological institutionalism'. All such descriptions are misleading. We always have to start from structures and individuals. There is no other viable explanatory strategy.

Some social scientists may uphold that social structures involve more than relations between individuals (where such relations also include social positions). If this were true, then (b) and $(\mathrm{b}+)$ would no longer be equivalent. But this would be mistake. A danger here is to reify social structure as something more than an interacting pattern of individuals, which would exist even if the individuals all disappeared. Social structures are essentially groups of interacting social individuals, possibly including social positions, and with emergent properties resulting from this interaction (Weissman, 2000).

Methodological individualists give the impression of being concerned about this danger. Some accounts seem to have the erroneous reification of structure as a target. However, to uphold that explanations must unavoidably involve structures as well as individuals does not imply that the former are independent of the latter. Everyone knows that if all individuals disappeared, then all structures would disappear as well.

Recognition of the danger of reification of structure does not mean that explanations of social phenomena can or should be reduced to individuals alone. Structures and isolated individuals are different things because interacting and isolated individuals are different things. By definition, isolated individuals have no causal interaction with other individuals. Structures depend on interacting individuals and would cease to exist if all the individuals or all their interactions disappeared. However, when a few people die most social structures remain in existence. The difference between structures and isolated individuals is also confirmed by the fact that every human individual is born into a world where structures already exist. Then individuals engage with this world, and play their part in supporting or changing these structures, while interacting with others.

Sophisticated advocates of methodological individualism are aware that the individual is a social being, enmeshed in relations with others. They are aware of the importance of culture, and that communication and language are deeply involved in constituting individuality. Consequently, the idea of a genuinely isolated individual, free of all social relations, is untenable (Davis, 2003). What many methodological individualists seem reluctant to do is to use this awareness to rule out such isolated individuals in the explanantia. Those that understand that only explanations of types (b) or $\left(b^{+}\right)$are possible, are eventually impelled like Hayek to abandon the term, or they relapse into vagueness concerning the critical difference between the two options (a) and (b).

Joseph Agassi's (1960, 1975) term 'institutional individualism' is better, but note that it gives one half of the story adjectival status while the other half has the prestige of being the noun. Why not 'individualistic institutionalism'? This symmetrically opposite bias is equally unwarranted. Both parts of the story are indispensable and no good reason has been provided to give one explanatory priority over the other. The chosen label should reflect this duality in the explanantia.

The question is then raised why the term 'methodological individualism' is so popular, especially when the broader version (b) involves both individuals and social structures. Perhaps there are several motives for the pursuit of 'methodological individualism'. Some may involve the mistaken idea that it is a necessary corollary or component of political individualism. This would confuse ideology with analysis. Others seem to stem from a more creditable notion that explanation in terms of micro-components is a key aim of science. 
However, as the examples of genes in biology and atomic particles in physics both illustrate, explanations in science are never in terms of micro-components alone: they always additionally involve interactive relations. Furthermore, if explanatory reduction to microcomponents were the legitimate aim, then this would be no justification for claiming that rock-bottom explanations are in terms of individuals. Instead we would face the daunting task of attempting to explain all social phenomena exclusively in terms of the most elementary subatomic particles. The very existence of social entities, and the social sciences devoted to their study, counters such an extreme reductionist agenda.

\section{Conclusion}

This article has shown that methodological individualism has no single accepted definition. Furthermore, it is typically used in ways that differ from the meaning given to it by Schumpeter, who coined the term.

Among several attributed meanings, the idea of 'explanations in terms of individuals' is identified here as both prominent and problematic. It is particularly problematic because it is unclear whether it means that explanations should be in terms of individuals plus relations between individuals, or in terms of individuals alone. This difference in explanantia turns out to be critical.

According to the 'folk theorem' proposed above, narrower explanations in terms of individuals alone have never actually been achieved. Attempts to start simply from individuals must actually start from individuals plus institutions. The advocates of this approach fail to carry out their own prescriptions.

All theories must first build from elements which are taken as given. However, the particular problems identified here undermine any claim that the explanation of the emergence of institutions can start from some kind of institution-free ensemble of (rational) individuals in which there is supposedly no rule or institution to be explained. Consequently, the project to explain the emergence of institutions on the basis of given individuals runs into difficulties, particularly with regard to the conceptualization of the initial state of nature from which institutions are supposed to emerge (Hodgson, 1998).

The broader version, where explanations are supposed to be in terms of individuals and relations between them, turns out to be equivalent to the proposition that explanations of social phenomena should be in terms of both individuals and social structures. There is nothing wrong with this proposition. But why call it methodological individualism, when structures and individuals are given equal status as elements in the explanation? If we wish to criticise notions that adequate explanations should be in terms of structures alone, then we should not adopt a term that connotes the mistaken idea that explanations can or should be in terms of individuals alone.

At the very minimum, the term 'methodological individualism' should not be used as an ill-defined mantra. If it is to be employed, then it must be much more clearly defined, overcoming the ambiguities in past usage. After over fifty years of widespread use of the term, advocates of 'methodological individualism' have been remarkably negligent in explaining its meaning. In fact, its usage is riven by deep contradiction and persistent vagueness. Given the deep conceptual problems and confusions surrounding the term, it might best be abandoned. 


\section{References}

Agassi, Joseph (1960) 'Methodological Individualism', British Journal of Sociology, 11(3), September, pp. 244-70.

Agassi, Joseph (1975) 'Institutional Individualism’, British Journal of Sociology, 26(2), June, pp. 144-55.

Aoki, Masahiko (2001) Toward a Comparative Institutional Analysis (Cambridge, MA: MIT Press).

Arrow, Kenneth J. (1994) 'Methodological Individualism and Social Knowledge', American Economic Review (Papers and Proceedings), 84(2), May, pp. 1-9.

Bogdan, Radu (2000) Minding Minds: Evolving a Reflexive Mind in Interpreting Others (Cambridge, MA: MIT Press). [intersubjectivity, autism]

Brennan, Geoffrey and Tullock, Gordon (1982) 'An Economic Theory of Military Tactics: Methodological Individualism at War', Journal of Economic Behavior and Organization, 3(3), pp. 225-42.

Bunge, Mario (2000) 'Ten Modes of Individualism - None of Which Works - And Their Alternatives', Philosophy of the Social Sciences, 30(3), pp. 384-406.

Caldwell, Bruce J. (2004) Hayek’s Challenge: An Intellectual Biography of F. A. Hayek (Chicago: University of Chicago Press).

Davis, John B. (2003) The Theory of the Individual in Economics: Identity and Value (London and New York: Routledge).

Dore, Ronald Philip (1961) 'Function and Cause', American Journal of Sociology, 26(6), December, pp. 843-53.

Douglas, Mary T. (1986) How Institutions Think (London and Syracuse: Routledge and Kegan Paul and Syracuse University Press).

Elster, Jon (1982) 'Marxism, Functionalism and Game Theory', Theory and Society, 11(4), pp. 453-82.

Field, Alexander J. (1979) 'On the Explanation of Rules Using Rational Choice Models', Journal of Economic Issues, 13(1), March, pp. 49-72.

Field, Alexander J. (1981) 'The Problem with Neoclassical Institutional Economics: A Critique with Special Reference to the North/Thomas Model of Pre-1500 Europe', Explorations in Economic History, 18(2), April, pp. 174-98.

Field, Alexander J. (1984) 'Microeconomics, Norms and Rationality', Economic Development and Cultural Change, 32(4), July, pp. 683-711.

Hahn, Frank H. (1984) Equilibrium and Macroeconomics (Oxford: Basil Blackwell).

Hayek, Friedrich A. (1942) 'Scientism and the Study of Society, Part I', Economica, 9, pp. 267-291.

Hayek, Friedrich A. (1948) Individualism and Economic Order (London and Chicago: George Routledge and University of Chicago Press). 
Hayek, Friedrich A. (1967) Studies in Philosophy, Politics and Economics (London: Routledge and Kegan Paul).

Hicks, John R. (1934) ‘Léon Walras’, Econometrica, 2(4), October, pp. 338-48.

Hodgson, Geoffrey M. (1988) Economics and Institutions: A Manifesto for a Modern Institutional Economics (Cambridge and Philadelphia: Polity Press and University of Pennsylvania Press).

Hodgson, Geoffrey M. (1998) 'The Approach of Institutional Economics', Journal of Economic Literature, 36(1), March, pp. 166-92.

Hodgson, Geoffrey M. (2006) 'What Are Institutions?', Journal of Economic Issues, 40(1), March, pp. 1-25.

Kincaid, Harold (1997) Individualism and the Unity of Science: Essays on Reduction, Explanation, and the Social Sciences (Lanham, ML: Rowman and Littlefield).

Knight, Jack (1992) Institutions and Social Conflict (Cambridge: Cambridge University Press).

Kontopoulos, Kyriakos M. (1993) The Logics of Social Structure (Cambridge: Cambridge University Press).

Lachmann, Ludwig M. (1969) 'Methodological Individualism and the Market Economy', in Streissler, Erich W. (ed.) (1969) Roads to Freedom: Essays in Honour of Friedrich A. von Hayek (London: Routledge and Kegan Paul), pp. 89-103.

Lukes, Steven (1969) 'Methodological Individualism Reconsidered', British Journal of Sociology, 19, pp. 119-29.

Lukes, Steven (1973) Individualism (Oxford: Basil Blackwell).

Machlup, Fritz (1937) 'Monopoloy and Competition: A Classification of Market Positions', American Economic Review, 27(3), September, pp. 445-51.

Mises, Ludwig von (1949) Human Action: A Treatise on Economics, $1^{\text {st }}$ edn. (London and New Haven: William Hodge and Yale University Press).

Nozick, Robert (1977) 'On Austrian Methodology’, Synthese, 36, pp. 353-92.

O’Neill, John (1973) Modes of Individualism and Collectivism (London: Heinemann).

Popper, Karl R. (1945a) 'The Poverty of Historicism III’, Economica, 11(1), May, pp. 69-89.

Popper, Karl R. (1945b) The Open Society and Its Enemies, 2 vols (London: Routledge and Kegan Paul).

Popper, Karl R. (1960) The Poverty of Historicism (London: Routledge and Kegan Paul).

Schumpeter, Joseph A. (1908) Das Wesen und der Hauptinhalt der theoretischen Nationalökonomie (München und Leipzig: Duncker und Humblot).

Schumpeter, Joseph A. (1909) 'On the Concept of Social Value', Quarterly Journal of Economics, 23(2), February, pp. 213-32.

Schumpeter, Joseph A. (1954) History of Economic Analysis (New York: Oxford University Press). 
Sober, Elliott (1981) 'Holism, Individualism, and the Units of Selection', in Asquith, P. D. and Giere, R. N. (eds) (1981) Philosophy of Science Association 1980, Vol. 2 (East Lansing, MI: Philosophy of Science Association), pp. 93-121.

Udéhn, Lars (2001) Methodological Individualism: Background, History and Meaning (London and New York: Routledge).

Udéhn, Lars (2002) 'The Changing Face of Methodological Individualism', Annual Review of Sociology, 28, pp. 479-507.

Watkins, John W. N. (1952a) 'Ideal Types and Historical Explanation', British Journal for the Philosophy of Science, 3(1), May, pp. 22-43.

Watkins, John W. N. (1952b) ‘The Principle of Methodological Individualism', British Journal for the Philosophy of Science, 3(2), August, pp. 186-9.

Watkins, John W. N. (1957) 'Historical Explanation in the Social Sciences', British Journal for the Philosophy of Science, 8(2), August, pp. 104-17.

Weber, Max (1968) Economy and Society: An Outline of Interpretative Sociology, 2 vols, translated from the German edition of 1921-1922 by G. Roth and C. Wittich (Berkeley: University of California Press).

Weissman, David (2000) A Social Ontology (New Haven, CT: Yale University Press).

Zwirn, Gregor (forthcoming) 'Methodological Individualism or Methodological Atomism: The Case of Friedrich Hayek’, History of Political Economy, forthcoming. 